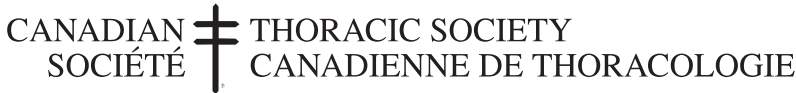

\section{President's report to the Annual General Meeting of the Canadian Thoracic Society, 2005}

am pleased to provide this report on the activities of 1 the Canadian Thoracic Society (CTS) executive and on my Presidency for 2004-2005. At the Annual General Meeting last year, I pledged to continue the initiatives of the organization that had been promoted by my predecessor, Dennis Bowie. Little did I know that this was much more easily said than done. We have survived major challenges posed by the abrupt change in administrative support that resulted from Ms Valoree McKay's dismissal from her position at the Canadian Lung Association (CLA). We are very pleased that Valoree is now wellestablished in her new role with a different organization. After some time, Ms Debbie Smith was formally assigned to support the CTS, initially part-time and, more recently, through full-time commitment. We are fortunate to benefit from the expert skills that Ms Smith brings to our organization.

Last year, I proposed to focus on three areas during my term: redefinition of relations between the CLA and the CTS, development of partnerships with other respiratory organizations and development of a Canadian meeting.

Our relationship with the CLA continues to evolve. There were extensive discussions early in 2005, including a special face-to-face meeting between our executives, to establish a constructive platform for going forward. While I am pleased that we were successful in this regard, we face further intense negotiations, as the CLA goes through a comprehensive strategic planning process that will be even more challenging, because they need to appoint a new CEO to replace Deirdre Freiheit, who will leave her position on December 1, 2005. CTS officers will need to commit considerable time to participating in these processes to ensure that our position and objectives are clearly understood by the CLA.

We have continued to strengthen our ties with the European Respiratory Society and the American College of Chest Physicians (ACCP). Our executives meet during major annual meetings and have developed open lines of communication among our offices. We have signed a joint membership agreement with the European Respiratory Society. Our annual educational session at

\section{Rapport du président à l'assemblée générale annuelle 2005 de la Société canadienne de thoracologie} 'ai le plaisir de vous présenter ce rapport des activités
du comité directeur de la Société canadienne de tho-
racologie (SCT) et de mon mandat à la présidence en 2004-2005. À l'assemblée générale annuelle de l'an dernier, je me suis engagé à poursuivre les projets favorisés par mon prédécesseur, Dennis Bowie. J'étais loin de me douter que c'était beaucoup plus facile à dire qu'à faire. Nous avons survécu aux immenses défis causés par les modifications abruptes au soutien administratif découlant de la démission de madame Valoree McKay de l'Association pulmonaire du Canada (APC). Nous sommes très heureux que Valoree soit maintenant bien établie dans son nouveau rôle au sein d'un autre organisme. Après un certain temps, madame Debbie Smith a été officiellement affectée au soutien de la SCT, à temps partiel pour commencer et, plus récemment, à plein temps. Notre organisme est chanceux de compter sur les compétences expertes de madame Smith.

L'an dernier, j'ai proposé d'orienter mon mandat vers trois secteurs : la redéfinition des relations entre l'APC et la SCT, la mise en place de partenariats avec d'autres organismes en santé respiratoire et la création d'un congrès canadien.

Nos relations avec l'APC continuent d'évoluer. Nous avons eu des discussions intensives au début de 2005, y compris une rencontre spéciale de nos deux comités directeurs afin de mettre sur pied une plateforme constructive pour aller de l'avant. Je suis satisfait des résultats, mais des négociations intenses s'annoncent puisque l'APC entreprend un processus de planification stratégique approfondi d'autant plus important qu'un nouveau chef de la direction devra remplacer Deirdre Freiheit, qui quittera son poste le $1^{\text {er }}$ décembre 2005. Les hauts dirigeants de la SCT devront consacrer beaucoup de temps à ces processus afin de garantir que l'APC comprend bien notre position et nos objectifs.

Nous avons continué à renforcer nos liens avec l'European Respiratory Society et l'American College of Chest Physicians (ACCP). Nos comités directeurs se sont rencontrés lors de grands congrès annuels et ont ouvert des lignes de communication entre nos bureaux. 
ACCP continues to flourish. The ACCP has welcomed CTS members to leadership roles within their organization, which will ensure our further collaborations. Helen Ramsdale is appointed to an American Thoracic Society planning committee, however, we have not developed more substantial interactions.

Within our Canadian community, we have promoted meetings of the Directors of Divisions of Respirology from academic centres and of Directors of Residency Training Programs. These initiatives are of major potential importance because they provide opportunity for networking across Canada and serve to consolidate our community. By better understanding the national perspective of issues in respirology, we expect that we can better coordinate our efforts and represent respiratory interests more effectively.

We have held extensive discussions on the topic of re-establishing a Canadian meeting. George Fox was instrumental in collating input from various interested parties. As the environment continues to change, we have held back from preparing a defined proposal. It is vital that we are sure of the purpose and target audience for any new initiative. It is also important that we seek to cluster CTS and respiratory group activities - if at all possible - so as to capitalize on potential synergies and economies (of time and cost). One strategy may be to cluster meetings of CTS committees and the Board, along with Respiratory Resident exam preparation or CANMEDS courses, or in association with the ResidentFellow Research Competition. There is no intent to change or compete with the very successful meeting that is held annually in conjunction with ACCP. I will continue to explore these opportunities.

Under the expert stewardship of Mark FitzGerald, the CTS Clinical Trials Committee has been very successful. The group has expanded to include representation from outside the CTS, in response to direction from the Canadian Institutes of Health Research. Consequently, the Canadian Respiratory Clinical Research Consortium has been founded. The first meeting of this group was held in Montreal, Quebec, on October 29 to 30, 2005, immediately before ACCP.

Irv Meyers has taken over from Jeremy Road as Chair of the Research Committee. He will be supported by Anne Van Dam, a newly appointed CLA employee who will be entirely committed to research matters. This is a welcome development because it was especially difficult this past year to meet the various deadlines and convene the necessary meetings for the process of adjudicating grants and the fellowship competition. Because this is a key area of CTS activities, it will be vital to ensure we have all the elements of the process securely in place ahead of time.

John Fleetham has taken on a number of initiatives as Chair of the Committee for Sleep Medicine, which has been very active. He arranged a recent meeting of the Committee and plans are in place to disseminate guidelines.
Nous avons signé une entente d'adhésion conjointe avec l'European Respiratory Society. Notre séance de formation annuelle à l'ACCP est florissante. L'ACCP a intégré des membres de la SCT à des rôles de chef de file, ce qui garantira la poursuite de cette collaboration. Helen Ramsdale est nommée à un comité de planification de l'American Thoracic Society, mais nous n'avons pas d'interactions plus substantielles avec cet organisme.

Au sein de la communauté canadienne, nous avons fait la promotion des réunions des directeurs des unités de santé respiratoire des centres universitaires et des directeurs de formation en résidence. Ces projets ont un potentiel considérable parce qu'ils procurent une possibilité de réseautage au Canada et consolident notre collectivité. En comprenant mieux la perspective nationale des enjeux en santé respiratoire, nous pourrons mieux coordonner nos efforts et représenter les intérêts en santé respiratoire avec plus d'efficacité.

Nous avons tenu des discussions intensives sur la réinstauration d'un congrès canadien. George Fox a colligé les commentaires des diverses parties intéressées. Puisque le milieu continue de changer, nous nous sommes abstenus de préparer un projet définitif. Il est essentiel qu'un nouveau projet soit doté d'une raison d'être et d'un public cible bien définis. Il est également important d'essayer de regrouper les activités de la SCT et des groupes de santé respiratoire, dans la mesure du possible, pour tirer profit de synergies et d'économies possibles (en temps et en argent). Une stratégie consisterait à regrouper les réunions des comités de la SCT et du conseil d'administration avec la préparation des examens des résidents en santé respiratoire ou des cours ProMEDS ou avec le concours de recherche des résidents et des boursiers. Nous n'avons pas l'intention de modifier le congrès très couru tenu chaque année conjointement avec l'ACCP ni d'y faire concurrence. Nous continuerons d'évaluer ces possibilités.

Sous l'égide experte de Mark FitzGerald, le comité des essais cliniques de la SCT obtient un franc succès. Le groupe a pris de l'expansion pour inclure des représentants de l'extérieur de la SCT par suite de l'orientation des Instituts de recherche en santé du Canada. Par conséquent, le consortium canadien de recherche clinique en santé respiratoire a été fondé. La première réunion de ce groupe a eu lieu à Montréal, au Québec, les 29 et 30 octobre 2005, tout de suite avant le congrès de l'ACCP.

Irv Meyers a remplacé Jeremy Road à la présidence du comité de recherche. Il sera appuyé par Anne Van Dam, une nouvelle employée nommée par l'APC qui se consacrera aux questions de recherche. C'est un apport bienvenu, parce qu'il était particulièrement difficile depuis un an de respecter les diverses échéances et de préparer les réunions nécessaires pour attribuer les subventions et les bourses. Puisque c'est un secteur essentiel des activités de la SCT, il sera capital de s'assurer d'avoir en place d'avance tous les éléments du processus. 
The dissemination of guidelines is a major activity of the CTS, with major efforts underway at present for asthma, sleep medicine and chronic obstructive pulmonary disease.

It is quite clear that our members are the most valuable assets of the CTS. We would like to enhance the brand or image of the CTS and to strengthen the link that members of our respiratory community feel to our organization. Many of our members hold positions of influence in other organizations and we would like that their participation be linked in some way to their membership in the CTS.

An important initiative that was launched this year at our meeting in Montreal was the creation of an active society, or Senate, of our Past-Presidents. Eighteen PastPresidents were able to attend this inaugural meeting chaired by Dennis Bowie.

In recent years, the CTS has participated in various advocacy activities. Last November we were deeply involved in the Day-on-the-Hill event organized by Luc Lapointe of the CLA. It seemed to be successful. However, we were very disappointed to find that respiratory disorders were not included in the list of chronic diseases to be targeted for attention by the federal government. It can be difficult to know what effect advocacy or lobbying efforts have had, but it is easy to see the effect of not getting the respiratory agenda acknowledged by our political leaders. At this time last year, we were confident that spirometry would be included, at least for a subset of participants, in the Canadian Health Survey. This is currently not in place despite our efforts.

The CTS has assembled a list of experts in centres across the country to be nominated to address issues for the media or government. We believe this is an important role for the CTS - to promote respiratory specialists as spokespersons for respiratory issues. This is one part of our strategy to enhance our profile.

Based on discussions with our incoming President, Gordon Ford, we would like to offer these thoughts for the future:

- We need to develop and strengthen relationships among the many elements of our respiratory community (residents, fellows, research, clinical, thoracic surgery, critical care, academic and primary care).

- We need to strengthen the link members have with the CTS, perhaps by increasing what the CTS does for them and perhaps by being more effective in advocating for respiratory issues. It is important that our members perceive value in being part of the CTS.

- We need to explore sources of funding other than from pharmaceutical companies, and explore alternate arrangements for raising funds from pharmaceutical companies to create more 'at-armslength' situations.
John Fleetham a entrepris divers projets à titre de président du comité des somnifères, qui a été très actif. Il a récemment organisé une réunion du comité, et la publication de lignes directrices est projetée.

La diffusion de lignes directrices représente un aspect important de la SCT. En ce moment, les principaux efforts en cours portent sur l'asthme, les somnifères et la maladie pulmonaire obstructive chronique.

De toute évidence, les membres constituent l'atout le plus précieux de la SCT. Nous aimerions améliorer la notoriété ou l'image de la SCT et renforcer les liens que les membres de la communauté de la santé respiratoire ont noués avec notre organisme. Bon nombre de nos membres occupent des postes influents au sein d'autres organismes, et nous aimerions que leur participation soit reliée d'une manière ou d'une autre à leur adhésion à la SCT.

Un autre projet important a été lancé cette année au congrès de Montréal. Il s'agit de la création d'une société active, ou "sénat », de nos anciens présidents. Dix-huit anciens présidents ont assisté à cette réunion inaugurale, présidée par Dennis Bowie.

Ces dernières années, la SCT a participé à diverses activités de défense d'intérêts. En novembre dernier, nous avons pris part à la journée sur la Colline organisée par Luc Lapointe, de l'APC. Elle a semblé obtenir un bon succès. Cependant, nous avons été très déçus de découvrir que les troubles respiratoires ne faisaient pas partie de la liste des maladies chroniques auxquelles le gouvernement fédéral accorderait son attention. Il peut être difficile d'évaluer les effets des efforts de défense d'intérêts et des pressions politiques, mais il est très facile de constater les conséquences de l'exclusion des préoccupations respiratoires par les dirigeants politiques. À la même date l'an dernier, nous avions bon espoir que la spirométrie fasse partie de l'Enquête nationale sur la santé, du moins pour un sous-groupe de participants. Ce n'est pas le cas, malgré nos efforts.

La SCT a colligé une liste d'experts de divers centres du pays pour qu'ils présentent des enjeux aux médias ou au gouvernement. Nous pensons que c'est un rôle important au sein de la SCT : promouvoir la présence de spécialistes en santé respiratoire comme porte-parole des enjeux respiratoires. C'est l'une des parties de notre stratégie visant à améliorer notre profil.

Pour faire suite à des discussions avec le nouveau président, Gorden Ford, nous tenons à vous présenter les réflexions suivantes pour l'avenir :

- Nous devons élaborer et renforcer les liens entre les nombreux éléments de la communauté de la santé respiratoire (résidence, bourses, recherche, chirurgie thoracique, soins intensifs, soins universitaires et primaires).

- Nous devons renforcer les liens des membres avec la SCT, peut-être en augmentant les services que leur rend la SCT et peut-être en défendant les enjeux respiratoires avec plus d'efficacité. Il est important que nos membres valorisent leur adhésion à la SCT. 
- We will promote the research agenda to the CLA and to national funding agencies, and seek to increase funding for respiratory research.

- We will work to create a relationship with the CLA that enhances the effectiveness and capitalizes on the distinct strengths of both orsganizations.

In closing, I would like to publicly thank the members of the executive committee and Ms Debbie Smith, for their unstinting efforts on behalf of the CTS.

P Gerard Cox MB FRCPC Past-President, Canadian Thoracic Society
- Nous devons explorer d'autres sources de financement que les sociétés pharmaceutiques, ainsi que d'autres ententes pour obtenir des fonds des sociétés pharmaceutiques afin de favoriser des situations plus conformes à la notion « sans liens de dépendance ».

- Nous ferons la promotion du programme de recherche auprès de l'APC et des organismes subventionnaires nationaux et chercherons à accroittre le financement en recherche respiratoire.

- Nous travaillerons à nouer des liens avec l'APC afin d'améliorer l'efficacité et de tirer profit des forces distinctes des deux organismes.

Pour terminer, je tiens à remercier publiquement les membres du comité directeur et madame Debbie Smith pour les efforts qu'ils n'ont pas ménagés au nom de la SCT.

P Gerard Cox MB FRCPC Président sortant, Société canadienne de thoracologie 


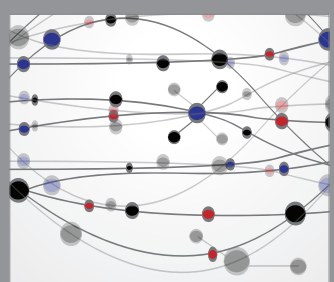

The Scientific World Journal
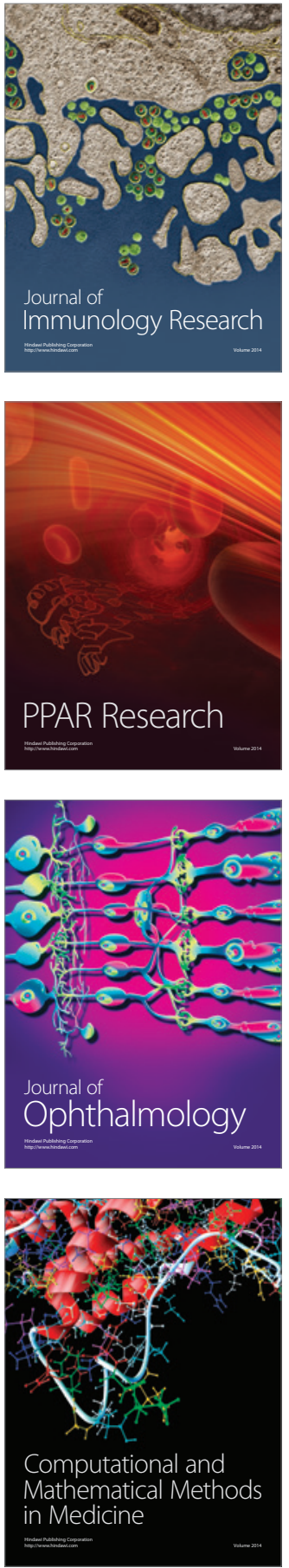

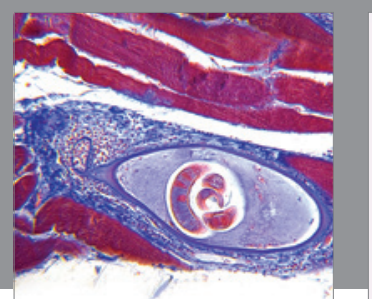

Gastroenterology Research and Practice

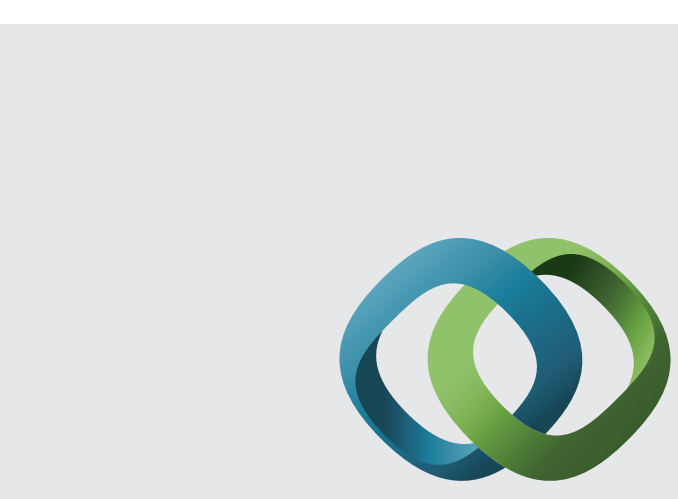

\section{Hindawi}

Submit your manuscripts at

http://www.hindawi.com
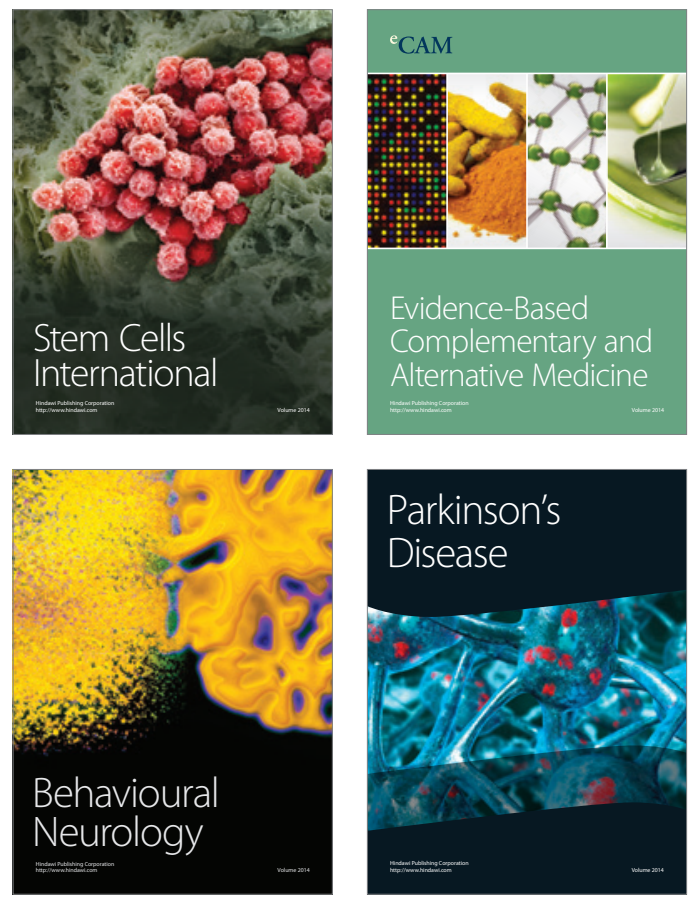
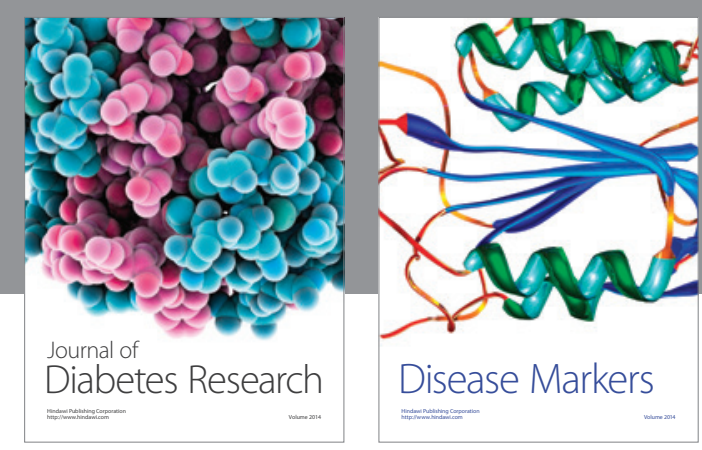

Disease Markers
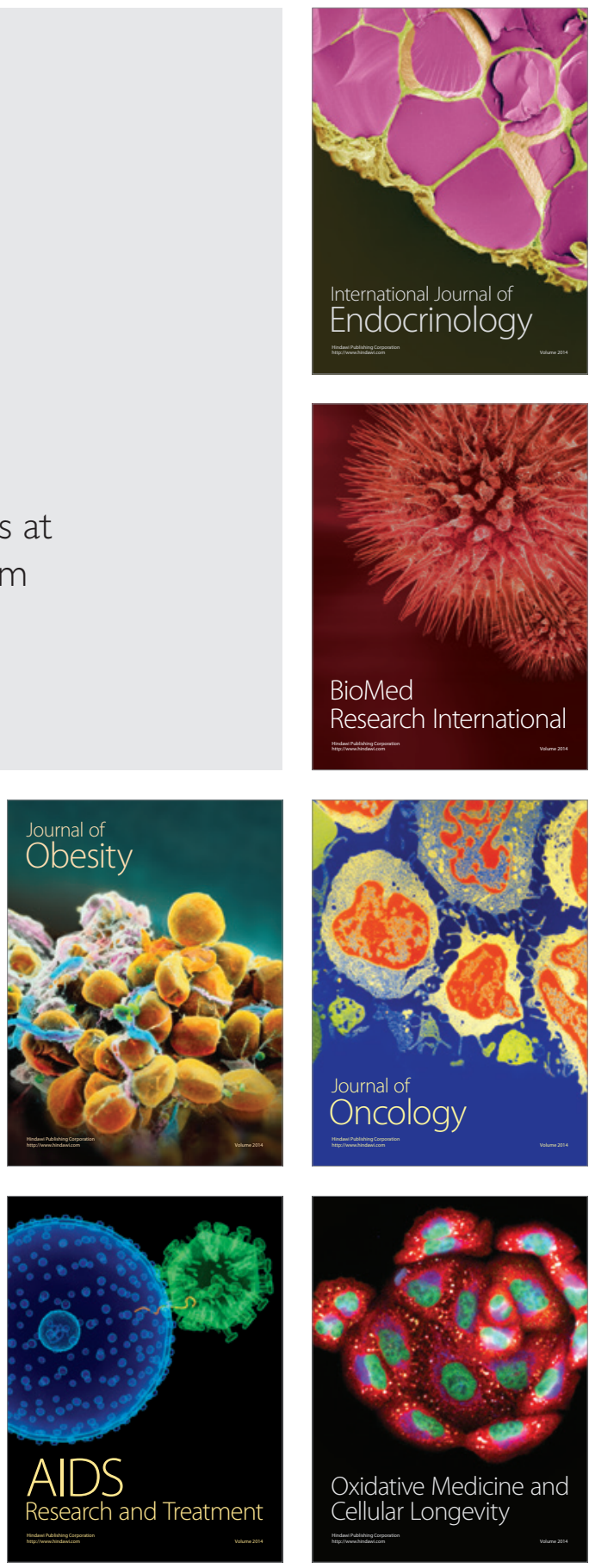